\title{
Vegetation cover estimate of arid and semi-arid regions by NOAA AVHRR data
}

\section{NOAA AVHRR データによる乾燥地・半乾燥地の植生被覆率推定}

\author{
Tserenkhuu Purevdorj* and Ryutaro Tateishi* \\ ツェレンフープレヴドルジュ・建石隆太郎
}

\begin{abstract}
NOAA Advanced Very High Resolution Radiometer (AVHRR) data were used to estimate green vegetation coverage of grasslands for semi-arid region. Two estimation models based on NDVI and TSAVI were applied to produce green vegetation cover images and compared with ground data collected in grasslands of Mongolia. There was significant agreement between ground data and the estimate of satellite data. The estimate by TSAVI has better accuracy for the green vegetation cover with low densities and the estimate by NDVI performs better result for middle and high vegetation cover. The result suggests that the joint use of the NDVI and TSAVI can improve accuracy of the estimate.
\end{abstract}

和文概要：半乾燥地域の草原の緑色植生被覆推定に, NOAAのAVHRRデータを適用した。NDVI と TSAVIに基づく 2 つの推定モデルで緑色植生被覆画 像を作成し，モンゴルの草原で収集した地上データと 比較した。地上デー夕と衛星デー夕の推定結果には有 意な関係があった。TSAVIによる緑色植生被覆の推 定では, 植生の少ない地域に対してはより正確になり， NDVIによる推定では植生の多い地域により良好な 結果が得られた。この結果は, NDVI と TSAVIの併 用が緑色植生被覆の推定精度を向上させうる事を示唆 している。

\section{Introduction}

Grasslands in semi-arid areas of Mongolia extend over large areas and efficient grassland monitoring and estimation of the grassland status in this region are considered very important for livestock breeding, increasing animal and agriculture production

${ }^{*}$ Center for Environmental Remote Sensing, Chiba University 千葉大学環境りモートセンシング研究センター 1-33, Yayoi-cho, Inage-ku, Chiba 263

干263 千葉市稲毛区弥生町1-33

「写真測量とリモートセンシング」VOL. 37，NO. 1， 1998 and economic forecasting. Green vegetation cover is an important factor in respect to the grassland status and it is more dynamic than many other factors. Quantitative information on the green vegetation cover is required in many arenas of global change research. Also green vegetation cover in arid regions is a sensitive indicator of land degradation.

Estimation of green vegetation cover amount is a difficult task for a complex ground surface where cover units are small, and cover types are composed of complex mixtures of vegetation and bare ground. In spite of the existing methods of vegetation monitoring, there is still no standard approach to quantitative estimate of green vegetation cover. Moreover, the most serious concern is that the existing methods still can not clearly provide quantitative estimates of green vegetation coverage in this region. Application of the remotely sensed satellite data to vegetation monitoring which enable the estimation green vegetation coverage, is fundamental to any remote sensing for environmental monitoring. On considering economic and scientific aspect of the estimation vegetation cover amount in 
relatively arid and semi-arid countries such as Mongolia, is quite actual and urgent problem. Particularly, it is very important to develop the efficient vegetation monitoring system using satellite data in the region.

Grassland monitoring requires a reliable and repeatable technique of accurate and timely information on vegetation for the spatial and temporal coverage. From this point, AVHRR provides an attractive data source for large survey area and has high probability of obtaining cloud-free data over a growing season for any given geographical area. The potential of AVHRR data for monitoring grassland production was recognized in many studies (Tucker et al. 1986, Prince et al. 1986).

The vegetation index approach, which was used in this study, is based on the assumption that consistent relationship exists between the amount of cover and vegetation index (VI), Vegetation indices are the most popular empirical tool to analyze remotely sensed data for vegetation monitoring. A variety of vegetation indices have been developed and have been found linear relationship with various characteristics of vegetation as leaf area index, biomass, leaf water content, chlorophyll and other biophysical characteristics of vegetation (Curran et al. 1992, Wiegand et al. 1991, and Everitt et al. 1984). There are various types of VIs which are proposed to application for estimating various characteristics of vegetation, however, very little attention has been given to the estimation of vegetation cover by VIs from AVHRR data and it is rarely tested. Moreover, the use of VIs is faced with the problem of choosing the most appropriate approach for particular interest of applications. Consequently, the development of functional relation between specific characteristics of vegetation and VIs from remotely sensed data has been become much more important in the environmental monitoring.

The aims of the research reported in this paper were to estimate green vegetation cover of semi -arid grasslands from NOAA AVHRR data.

\section{Study area}

Our experiment was conducted on grasslands in Mongolia. Mongolia is geographically located from approximately $40^{\circ}$ to $52^{\circ} \mathrm{N}$ latitude and $90^{\circ}-120^{\circ} \mathrm{E}$ longitude. The climate of the country is considered semi-arid and arid. The mean annual precipitation is $200-300 \mathrm{~mm}$ and its $80-90$ percent falls from May to September. The typical climatic feature is sharp temperature fluctuation. The territory of Mongolia is divided into several natural zones such as mountain, mountain steppe, plain steppe, desert steppe and the Gobi-desert. Mountain steppe, plain steppe and desert steppe are the most significant and large area for the cattle-breeding and agriculture of Mongolia. Authors selected three representative places, each of them belongs to mountain steppe, plain steppe and semi-desert steppe respectively. Sampling sites were chosen in the large homogeneous areas of grasslands so as to be best represent the grasslands and concentrated in the low and middle vegetation densities region which are most difficult and important to detect by AVHRR data.

The first group of test sites includes two sites (Site 1 and Site 2 in Table 1) in the southern portion of Mongolia. The sites are located in territory of Dundgovi aimag, approximately $300 \mathrm{~km}$ south of the

Table 1 Date and location of the ground measurements.

\begin{tabular}{ccc}
\hline Site number & Date & $\begin{array}{c}\text { Location } \\
\text { (degree, minute) }\end{array}$ \\
\hline 1 & 1996.08 .08 & $45,37,325 \mathrm{~N}$ \\
& & $106,14.019 \mathrm{E}$ \\
2 & 1996.08 .10 & $46,22.011 \mathrm{~N}$ \\
& & $105,46.907 \mathrm{E}$ \\
\multirow{2}{*}{3} & 1996.08 .14 & $47,22.718 \mathrm{~N}$ \\
& & $106,20.875 \mathrm{E}$ \\
4 & 1996.08 .20 & $47,41.923 \mathrm{~N}$ \\
& & $108,03.770 \mathrm{E}$ \\
\multirow{2}{*}{5} & 1996.08 .27 & $48,09.075 \mathrm{~N}$ \\
& & $104,45.486 \mathrm{E}$ \\
6 & 1996.09 .01 & $48,20.206 \mathrm{~N}$ \\
& & $104,06.429 \mathrm{E}$ \\
\hline
\end{tabular}


capital city Ulaan baatar and belong to the semi -desert Central Asian regions. Elevations in the area range from 1000 to $1500 \mathrm{~m}$ above sea level and soil is gray brown and desert steppe brown with pebbles. Precipitation averages $150-200 \mathrm{~mm}$ /year, coming primarily in the summer and winter as rain and snow.

The vegetation at these sites was mostly healthy and green, and there was in some places dying senescent grass. The prevailing plants in these sites are: Stipa gobica, S. glareosa, Cleistogenes squarrosa, stipa klemenzii, and Cleistogenes songorica and secondly prevailing plants are the Kochio prostrata, Allium polyrrhizum, and A. mongolicum.

The second group of test sites (Site 3 and Site 4 in Table 1) belongs to the plain steppe, which is widely spread out in between the small mountains and valleys and this is the main area for the cattle folder and nutrition in the country throughout a year. The prevailing herbs and plants in this plain steppe are: Stipa. capillata, S. decipiens, S. grandis, Cleistogenes Squarrosa (Poa attenuata, Festuca lenesis, F. sibirica Helictotrichon schellianum, Carex pediformis, Filifolum sibiricum, Scabiosa comosa). In this area the soil is brown and elevations range from 1000 to $1500 \mathrm{~m}$ above sea level. Precipitation averages $250-300 \mathrm{~mm} /$ year.

The third group of test sites includes two sites (Site 5 and Site 6 in Table 1) belonging to the mountain steppe widely spread out in central, north and western regions of Mongolia and have usually dark brown and brown soil. Grasses widely spread out in this area are F. Lenensis, F. sibirica, Polygonum Angustifoluim, Coluria geodes, Crossularia acicularis, Pentaphylloides fruticosa, Elevations in the area ranges from 1500 to $2000 \mathrm{~m}$ above sea level. Precipitation averages $300-400 \mathrm{~mm} /$ year.

\section{Methods}

The research methodology was developed in several stages : field measurements of vegetation cover reflectances, model formulation, ground measure- ments of green vegetation cover, satellite data processing and validation of the estimate of green vegetation cover. The field measurements of vegetation cover reflectance and model formulation were reported in our previous works (Purevdorj et al., 1996, Purevdorj et al., 1997a).

\subsection{Function for the estimate of percent vegetation cover by VI}

The semi-empirical model was used in the study for the estimate of green vegetation cover from NOAA AVHRR data in the semi-arid region. Estimating model was formalized by applying a regression technique to the data where the percent vegetation cover was held as the dependent variable, while the VIs values was held as the explaining variable (Purevdorj et al., 1997a). The equations (formulas (1) and (2)) which describe empirical relationships between percentage green vegetation cover and VIs were derived using spectral reflectance measurement at ground simulating AVHRR data.

cover $(\%)=-4.337-3.733^{*} \mathrm{NDVI}+161.968^{*} \mathrm{NDVI}^{2}$

cover $(\%)=1.062+43.5442 *$ TSAVI

$$
+97.817^{*} \text { TSAVI }^{2}
$$

Our experimental results (Purevdorj et al., 1996) indicated that NDVI and TSAVI perform better result than other VIs for the estimate of green vegetation cover. Therefore, in the study these two polynomial equations of second order were chosen as a equation for estimating percent green vegetation cover from the NOAA AVHRR data. The NDVI and TSAVI values used in the polynomial equations of second order were calculated by following formulas (formulae ( 3 ), Rouse et al. 1974 ; formulae ( 4 ), Baret et al. 1991) :

$\mathrm{NDVI}=\frac{\mathrm{NIR}-\mathrm{RED}}{\mathrm{NIR}+\mathrm{RED}}$

TSAVI $=\frac{a \cdot(N I R-a \cdot R E D-b)}{(\operatorname{RED}+a \cdot N I R-a \cdot b)}$

Where RED and NIR are Channel 1 and Channel 2 of AVHRR. 
$\mathrm{a}$ and $\mathrm{b}$ in TSAVI are slope and intercept of a soil line which are defined by ground reflectance value of bare soil (Ts. Purevdorj et al. 1997b). Linear regression was used to generate slope and intercept values relating to Red and NIR reflectances space of the soil line for the test sites (Ts. Purevdorj et al., 1997). The resulting of the slope and intercept were $\mathrm{a}=1.0725$ and $\mathrm{b}=0.063$ respectively.

\subsection{Field measurement of vegetation cover}

Ground data collection in Mongolia was carried out during August and September 1996. The aim of the field measurements was to estimate the vegetation cover amount for test sites. The geographical location was determined by GPS camera "Konica". A total of 6 sites were sampled during the ground truth campaign (Table 1) with one sample plot in each test site. Sampling scheme was similar for all test sites and carried out as following. In each of the test sites, random about $1 \mathrm{~km} \times 1 \mathrm{~km}$ area was chosen. For the site were sampled 25 points as shown in Figure 1 and the color photographs of ground cover of the points were taken. from vertical direction. Then vegetation cover of each point was estimated by counting numbers of green vegetation pixels using pixel value of red, green, and blue band of the

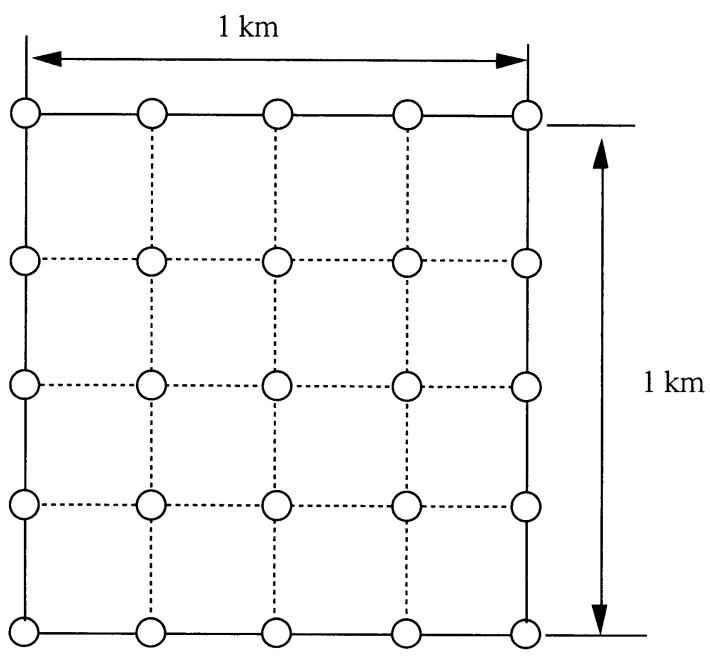

Figure 1 Sampling Scheme of ground measurement for vegetation cover.
Table 2 Ground measurement of green vegetation cover for test sites.

\begin{tabular}{c|rrrrrr}
\hline \multirow{2}{*}{$\begin{array}{c}\text { Point } \\
\text { number }\end{array}$} & \multicolumn{5}{|c}{ Percent vegetation cover } \\
\cline { 2 - 7 } & Site 1 & Site 2 & Site 3 & Sise 4 & Site 5 & Site 6 \\
\hline 1 & 10.63 & 17.85 & 36.50 & 46.30 & 8.68 & 14.08 \\
2 & 11.73 & 23.25 & 20.10 & 50.20 & 8.31 & 11.95 \\
3 & 10.96 & 18.45 & 29.86 & 52.70 & 7.07 & 16.57 \\
4 & 15.07 & 18.27 & 23.78 & 47.60 & 9.55 & 15.65 \\
5 & 9.74 & 8.79 & 31.86 & 44.40 & 7.47 & 9.86 \\
6 & 11.56 & 16.09 & 23.05 & 39.10 & 14.77 & 15.17 \\
7 & 15.51 & 16.42 & 27.59 & 36.50 & 15.69 & 10.21 \\
8 & 13.69 & 10.17 & 18.48 & 41.20 & 6.73 & 11.85 \\
9 & 13.38 & 11.78 & 31.41 & 37.90 & 9.47 & 14.62 \\
10 & 15.08 & 9.32 & 26.71 & 32.60 & 8.40 & 10.91 \\
11 & 9.48 & 13.92 & 26.47 & 38.90 & 7.92 & 15.25 \\
12 & 17.51 & 13.04 & 26.61 & 41.50 & 10.26 & 17.27 \\
13 & 12.54 & 10.17 & 26.60 & 40.20 & 4.40 & 10.55 \\
14 & 11.69 & 10.85 & 16.20 & 49.60 & 8.01 & 12.85 \\
15 & 13.07 & 15.79 & 19.39 & 55.20 & 6.67 & 11.77 \\
16 & 19.38 & 14.25 & 39.73 & 34.50 & 4.97 & 13.17 \\
17 & 14.63 & 13.64 & 28.15 & 48.30 & 7.88 & 10.63 \\
18 & 14.62 & 11.67 & 21.98 & 49.30 & 7.59 & 13.31 \\
19 & 14.87 & 10.35 & 22.23 & 51.50 & 9.95 & 21.63 \\
20 & 15.43 & 13.58 & 21.02 & 48.60 & 9.61 & 18.88 \\
21 & 13.32 & 13.73 & 28.57 & 46.70 & 8.85 & 26.71 \\
22 & 17.81 & 15.26 & 26.41 & 45.60 & 10.42 & 17.10 \\
23 & 12.38 & 23.55 & 24.43 & 44.80 & 8.86 & 23.59 \\
24 & 9.56 & 9.56 & 17.45 & 41.20 & 9.65 & 15.08 \\
25 & 11.84 & 10.78 & 18.64 & 40.60 & 8.82 & 15.27 \\
\hline Mean & 13.42 & 14.02 & 25.33 & 44.20 & 8.80 & 14.96 \\
Standard & 2.60 & 4.02 & 5.81 & 5.90 & 2.44 & 4.23 \\
\hline deviation & & & & & & \\
\hline & & & & & &
\end{tabular}

digitized photographs. Percent vegetation cover was calculated as a percentage of number of pixels corresponding to green vegetation cover of the image per total number of pixels in the photograph (Purevdorj et al., 1996). In order to distinguish the pixels corresponding to green vegetation cover from other pixels such as a soil, senescent grass and shadow, we use following conditions:

1. $g>r, g>b$ where $g, r$ and $b$ are pixel value of green, red and blue band respectively, and 2. $g>X, X-i$ s a critical value of green band which is determined depending on brightness of the photograph.

If a pixel satisfy the above two conditions, this pixel is considered as a green vegetation pixel The total 
vegetation cover amount for each test site was determined as mean of the percents vegetation cover estimated for 25 sample points. The estimates of green vegetation cover for the sampling sites are presented in Table 2.

Error associated with the estimates of percent vegetation cover is very difficult to quantify. One of the error source that can occur in the study is the small size of sampling area and sampling number for each test site. It is possible to cause some errors in the estimate of vegetation cover amount for large area. However, it does have the advantage of sampling sites which are located in very large homogeneous grasslands suitable for the use AVHRR data. Calculated values of standard deviation given in Table 2 show that vegetation density is relatively constant.

\section{Image processing}

In order to compare the ground measurements of percent vegetation cover with the estimate from satellite data, were used NOAA AVHRR High Resolution Picture Transmission (HRPT) data. The images acquired during the field measurement were processed and visually examined on the basis of false color composites to ensure that only cloud -free data were used for the estimate. Most of the images acquired during the field measurements were partially or almost completely covered by cloud over the test sites. From the images, two scenes were selected. These two scenes acquired on August 3, 1996 in receiving station of Ministry of Nature and Environment of Mongolia and on
August 12, 1996, from the archives of the EROS DATA CENTER (USA) were as least cloudy image for test sites. Characteristics of the images are given in Table 3. All of the NOAA AVHRR data available for us were raw data and was necessary to do pre

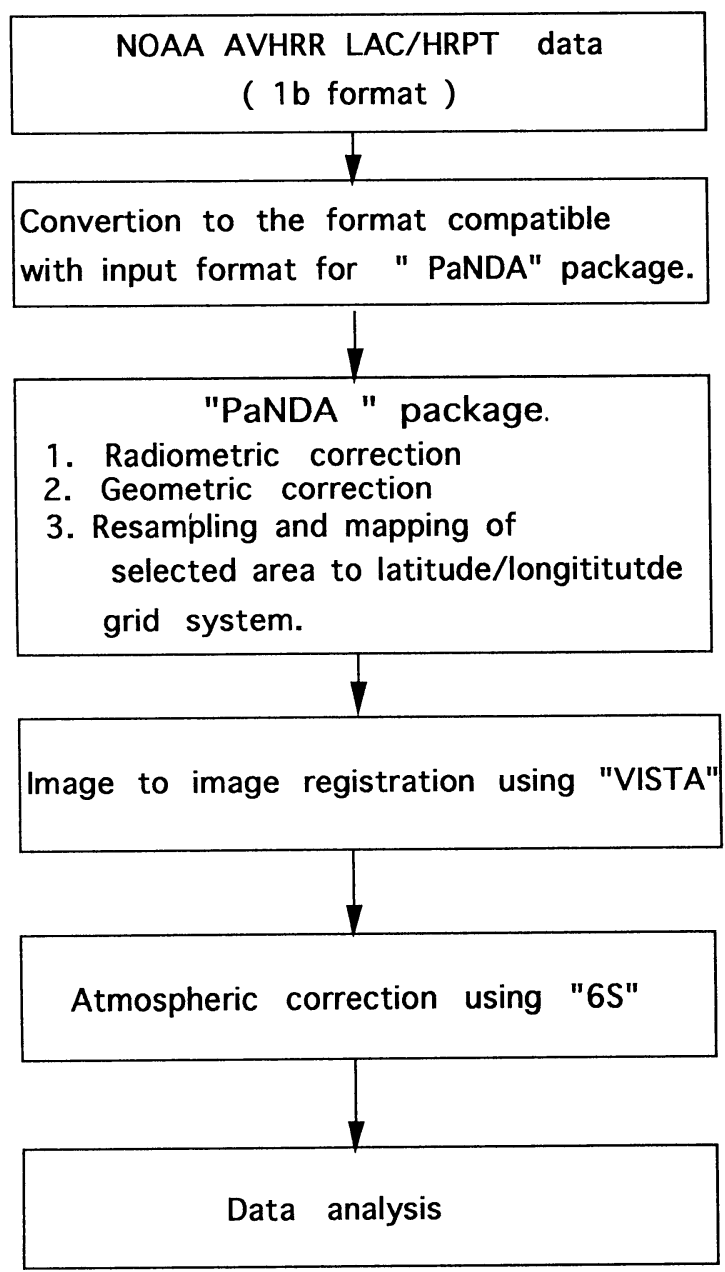

Figure 2 General flow of the NOAA AVHRR data processing.

Table 3 Characteristics of the selected images

\begin{tabular}{lcc}
\hline \multicolumn{1}{c}{ File name } & N49680306.0G0 & N49681206.0G5 \\
\hline Satellite & NOAA-14 & NOAA-14 \\
Date & August 3 & August 12 \\
Start time of obser. & $6.47 .59,973$ (UT) & $6.50 .43,140(\mathrm{UT})$ \\
Pixel & 2048 & 2048 \\
Line & 4406 & 4865 \\
Acquired location & Ulaanbaatar (Mongolia) & NOAA NESDIS \\
\hline
\end{tabular}


-processing of radiometric and geometric corrections. Subscenes of $1200 \times 1200$ pixels for the study areas were extracted and mapped into Plate Carree projection. The mapped images are located between 40 to 50 degree north latitude and 100 to 110 degree east longitude. The processing sequence for each AVHRR image is shown in Figure 2. LAC/HRPT data received from Mongolia has different format from the input format for "PaNDA" package which to be used to preprocessing. Therefore, these data were converted to the format compatible with "PaNDA" package.

\subsection{Geometric correction}

The images were geometrically corrected by "PaNDA" using ground control points. The ground control points were obtained from Operational Navigation Chart (1: 1000000, Defense Mapping Agency Aerospace Center, St. Louis, Missouri, 1988).

\subsection{Atmospheric correction}

Visible and near-infrared radiation reaching the satellite is differentially scattered and absorbed by atmospheric components. Compensation for atmospheric effects is important when NOAA AVHRR data used for vegetation monitoring. This is specially true when spectral vegetation indices are used from arid and semi-arid areas (Tanre et. al 1992). The principal sources of atmospheric effects in AVHRR channel 1 and channel 2 data are from differential molecular scattering, aerosol scattering, ozone absorption, and water vapor absorption, often complicated by viewing geometry and illumination. These effects are highly variable, and at times are compensating (Tanre, et. al 1992). The atmospheric effects change not only the signal amplitude, but also its spectral characteristics. Therefore, the measured signal must be corrected for atmospheric effects. In the study atmospheric correction of the AVHRR Channel 1 and Channel 2 was carried out using "6S" program (Goddard Space Flight Center, USA). The source code of the " $6 \mathrm{~S}$ " were obtained by
FTP from ftp : //kratmos. gsfc. nasa. gov $/ 6 \mathrm{~S}$ and compiled in SUN SPARC system. However, correction of large image using " $6 \mathrm{~S}$ " is complicated because in each step of the calculation, the user should enter input conditions for each pixel to be corrected. In addition, the " $6 \mathrm{~S}$ " program was developed for most general case and the user can modify for his or her own specific purpose. Taking account above mentioned point of view, authors adopted "6S" code for NOAA AVHRR data corrections.

The correction results show that low value of the Channel 1 is reduced due to the removal of path radiance caused by Rayleigh and aerosol scattering. It was observed that when reflectance of the Channel 1 is less than about 9 and 6 for non vegetated and vegetated area respectively, the corrected reflectance is decreased due to over correction. With increasing reflectance of Channel 1, the magnitude of the correction is increased. Reflectance of the Channel 2 in study area are mostly greater than 0.1 due to higher surface reflectances. Relatively high surface reflectances and low Rayleigh scattering of near -infrared radiation, means that path radiances were less than surface reflectance. Therefore, it was not observed the decrease of the reflectances in Channel 2. The dynamic range of correction for Channel 2 was significantly greater than it was for the Channel 1.

After atmospheric correction of the Channel data by the above described method, NDVI values were calculated and made the histogram. The comparison of the histogram indicates that there is intrinsic differences between the atmospherically corrected and uncorrected NDVI values (Figure 3). It is considered that this difference is caused by atmospheric attenuation and for this reason reflectance value of channel data are changed. As Channel 1 and Channel 2, Figure 3 shows a similar tendency for NDVI, that is larger corrections for higher NDVI. The results show that maximum value of the uncorrected and corrected NDVI was about 0.62 and 0.79 respectively. However, since number of the pixels with high value of NDVI was relatively small, they 


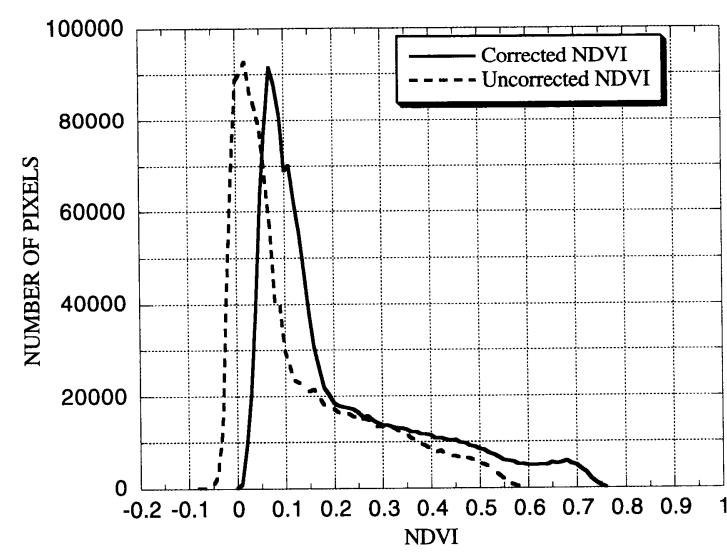

Figure 3 Histogram of atmospherically corrected and uncorrected NDVI of NOAA AVHRR (3 August, 1996, NOAA AVHRR).

do not appear distinctly in Figure 3. The comparison the histogram of corrected NDVI with the ground truth data acquired by spectrometer measurements of the various land cover reflectance in vegetated area of Mongolia (Yokoyama et. al 1994), demonstrates that the correction results are very close to ground truth data. In summary, the results show the importance of the atmospheric correction in AVHRR measurements of surface reflectances in vegetation monitoring.

\section{Satellite data analysis}

After radiometric, geometric, and atmospheric correction of Channel 1 and Channel 2 data, VIs values were calculated regarding to formulas described in the section 3.2. The calculated VIs data sets were formed into maximum value composite images. This technique minimizes cloud contamination and shadow effects (Holben 1986). The derived relationships between percent vegetation cover and VIs values (regression equations (1) and (2) described in the section 3.2), were applied to the corrected AVHRR Channel data to produce images of the vegetation cover estimates for test sites. The resulting vegetation cover images (Figure 4) are the first of their type for the Southern and Central region in Mongolian grasslands. From the estimated vegetation cover image were extracted $5 \times 5$ pixels boxes, centered on the geographic coordinates of each ground data collection site. The mean and standard deviation of the percent vegetation cover estimated by NDVI and TSAVI for these 25 pixels were calculated for each site.

The accuracy of the estimate were calculated as absolute differences between the ground measurement and the estimated values from satellite data (Table 4). The average absolute errors of the estimate by NDVI and TSAVI were 7.02 and 7.76 per cent respectively for the test sites and it shows that the errors of the estimate by NDVI is slightly lower than the estimate by TSAVI. However, the results show that accuracy of the estimate by TSAVI is higher than the estimate by NDVI when green vegetation coverage is a low except site 6 . It is important to note that it may have occurred some errors in the comparison of the ground measurement and satellite estimate for the Site 5 and Site 6 because of differences in the date of ground mea-

Table 4 Absolute errors of the satellite estimate of green vegetation cover.

\begin{tabular}{cccccc}
\hline Sites & $\begin{array}{c}\text { Ground } \\
\text { truth }\end{array}$ & $\begin{array}{c}\text { Estimated } \\
\text { by NDVI }\end{array}$ & $\begin{array}{c}\text { Estimated } \\
\text { by TSAVI }\end{array}$ & $\begin{array}{c}\text { Absolute } \\
\text { error (NDVI) }\end{array}$ & $\begin{array}{c}\text { Absolute error } \\
\text { (TSAVI) }\end{array}$ \\
\hline Site 1 & 13.42 & 3.8 & 6.36 & 9.62 & 7.06 \\
Site 2 & 14.02 & 4.88 & 5.48 & 9.14 & 8.54 \\
Site 3 & 25.33 & 18.48 & 17.88 & 6.85 & 7.45 \\
Site 4 & 44.2 & 39.32 & 32.72 & 4.88 & 11.48 \\
Site 5 & 8.8 & 16.32 & 5.64 & 7.52 & 3.16 \\
Site 6 & 14.96 & 10.84 & 6.12 & 4.12 & 8.84 \\
\hline $\begin{array}{c}\text { Mean absol. } \\
\text { error }\end{array}$ & & & 7.02 & 7.76 \\
\hline
\end{tabular}



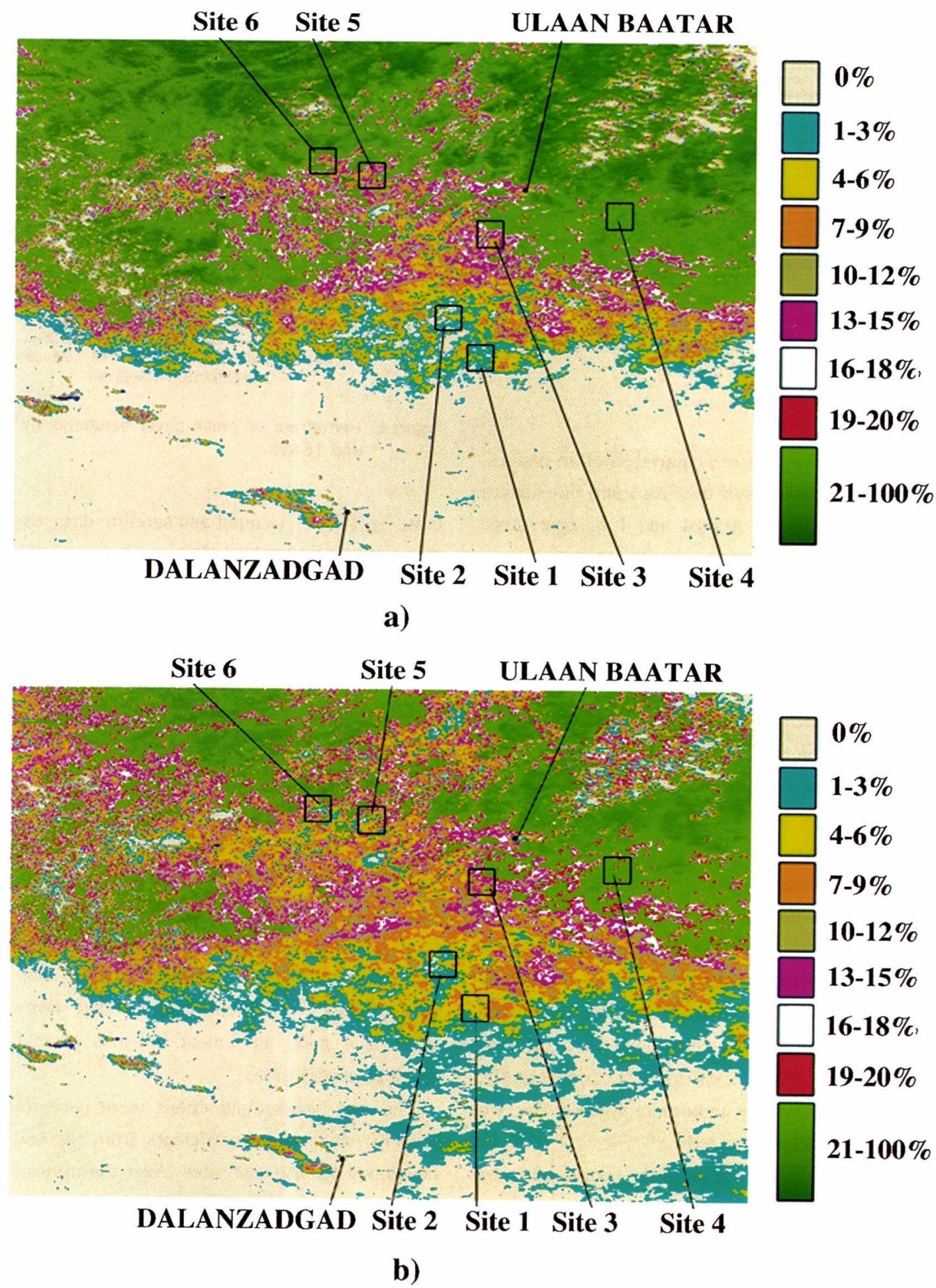

Figure 4 Green vegetation cover images

a)-the estimate by NDVI, b)-the estimate by TSAVI. 


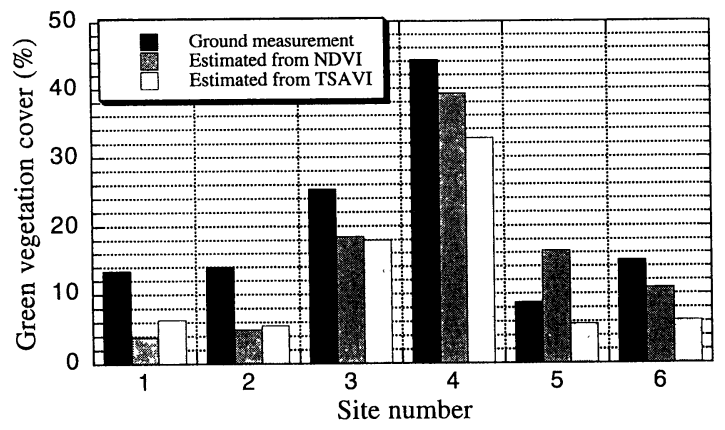

Figure 5 Comparison ground and satellite astimate of green vegetation cover.

surement and the date of acquired satellite images. Ground measurements of the Site 5 and Site 6 were carried out on 27 of August and 1 of September while satellite data used for the analysis were composite image of 3 August and 12 August. In addition to that, green vegetation cover in Mongolia reaches the peak usually in the end of July and declines from the middle of August. Therefore we assume that the satellite estimate of green vegetation cover is little higher than the percent vegetation cover which would have estimated in the end of August.

The accuracy of the estimate by NDVI in the Table 4 has been became higher than the estimate by TSAVI with increasing green vegetation cover. Taking these points of view into account, from the comparison of the ground measurement and satellite estimate demonstrated in Figure 5, it can be concluded that percent vegetation cover estimated from the AVHRR data were lower than the estimate from the ground measurement. Consequently, the results suggest that maximum value of the two estimates should be selected.

Table 4 and the histogram of the estimated green vegetation cover demonstrated in Figure 6 show that the TSAVI performs better result in areas with low vegetation densities area while calculated absolute error of the estimate by NDVI were less than those of the TSAVI except site 6. Therefore, it is reasonable to suppose that the NDVI is a better indicator when the estimate is higher than the esti-

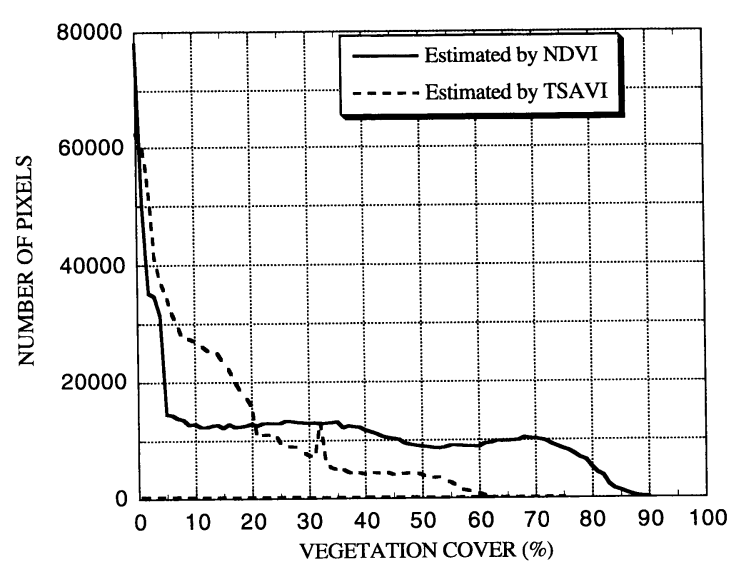

Figure 6 Histogram of green cover estimates by NIVI and TSAVI.

mate by TSAVI. Ground and satellite data analysis shows that the TSAVI is less sensitive to soil background effects. Thus the joint use of the TSAVI and NDVI could lead to better accuracy of the estimate green vegetation cover because TSAVI is a good estimator of low vegetation cover and NDVI is a good estimator of middle and high vegetation cover.

\section{Conclusion}

Green vegetation cover was estimated from NOAA AVHRR with a satisfactory accuracy and the similarity between the estimated green cover from satellite and ground data is remarkable. Standard deviation of the estimate from ground and satellite data were comparable and that shows that there is a good agreement between ground and satellite observation.

The soil background effect were corrected by TSAVI which uses coefficients from the soil line developed for the test sites. Also the atmospheric effects were corrected by " $6 \mathrm{~S}$ " program and the correction results that maximum difference between corrected and uncorrected NDVI was about 0.18 unit in high vegetated area. Therefore, accurate atmospheric correction is one of the most important factors to improve an accuracy of the estimate of the vegetation characteristics. 
TSAVI has better accuracy in the estimate of green vegetation cover with low vegetation densities and accuracy of the estimate by NDVI has been became higher than the estimate by TSAVI with increasing green vegetation cover. In addition, mean error of the estimate show that NDVI gives best estimate of the percent green vegetation cover for wide range of grass densities.

The analysis showed that vegetation cover value estimated by TSAVI were lower than the estimate by NDVI when NDVI has better accuracy, and that vegetation cover value estimated by NDVI were lower than the estimate by TSAVI when TSAVI has better accuracy. Consequently, maximum values of these two estimates were a close to ground measurements of green vegetation cover.

The analysis showed that percent vegetation cover estimated from satellite data were lower than the estimate from the ground measurements for the test sites. In summary, the results show that green vegetation cover amount can be estimated from AVHRR data with certain accuracy by NDVI and TSAVI using a polynomial equation of second order, and that the joint use of the two estimating models based on the NDVI and TSAVI can improve accuracy of the estimate green vegetation cover.

From this study, it is concluded that, on the basis of the results, the method in this study to estimate vegetation cover has been shown to be useful in estimating green cover in grasslands and can be applied to NOAA AVHRR data for the estimate of green vegetation cover of grassland in arid and semi -arid regions.

\section{Acknowledgment}

The authors gratefully acknowledge Professor T. Furuya, Chiba University, for his helpful advice, Professor R. Yokoyama, Iwate University, for his support and providing facilities for the image processing, Dr. Honda, Chiba University, for his contribution and assistance to the field measurement in Mongolia, and Dr. T. Ishiyama for providing the spectro radiometer and other equipment used to collect ground truth data. The authors also gratefully acknowledge the anonymous referees for their valuable comments and constructive criticism.

(受付日1997.9.4, 受理日1998.1.12)

\section{References}

Journals :

BARET, F. and GUYOT, G., 1991, Potentials and limits of vegetation indices for LAI and APAR assessment, Remote Sens. Environ. 35, 161-173.

CURRAN, P. J., JENNIFER, L. D., and HENRY, L. G., 1992, Seasonal LAI in slash pine estimated with Landsat TM, Remote Sens. Environ., 39, 3-13.

DYMOND, J. R., STEPHENS, P. R., NEWSOME, P. F., and WILDE, R. H., 1992, Percent vegetation cover of a degrading rangeland from SPOT. International journal of remote sensing, VOL. 13, NO. 11, 1999-2007.

EVERITT, J. H., ESCOBAR, D. E., and RICHARDSON, A. J., 1984, Estimating grassland phytomass production with near-infrared and mid-infrared spectral variables, Remote Sens. Environ. 30, 257 $-261$.

HOLBEN, B. N., 1986, Characteristics of maximum -value composite images from temporal AVHRR data, Int. J. Remote Sensing, VOL. 7, NO. 11, 1417 -1434 .

HUTE, A. R., JACKSON, R. D., and POST D. F., 1985, Spectral response of a plant canopy with different soil backgrounds, Remote Sens. Environ. 17, 37-53.

MAJOR, D. J., BARET, F., and GUYOT, G., 1990, A ratio vegetation index adjusted for soil brightness, Int. J. Remote Sensing, VOL. 11, NO. 5, 727-740.

PRINCE, S. D., and TUCKER, C. J., 1986, Satellite remote sensing of rangelands in Botswana II : NOAA AVHRR and herbaceous vegetation, Int. J. Remote Sensing, 7, 1555-1570.

ROUSE, J. W., HAAS, R. H., SCHELL, J.A., and DEERING, D. W., 1973, Monitoring vegetation systems in the great plains with ERTS, Third ERTS Symposium, NASA.

TUCKER, C. J. and SELLER, P. J., 1986, Satellite 
remote sensing of primary production, Int. J. J., 1992, Atmospheric correction algorithm for Remote Sensing, 7, 1395-1416. NOAA-AVHRR products: theory and application, PUREVDORJ, TS., TATEISHI, R., ISHIYAMA, T. IEEE Trans. Geosci. Remote Sensing, VOL. 30, NO. and HONDA, Y., 1997b Relationships between per2, 231-248.

cent vegetation cover and vegetation indices, Int. J. PUREVDORJ, TS., TATEISHI, R. and Remote Sensing, (in Press)

WIEGAND, C. L., RICHARDSON, A. J., ESISHIYAMA, T., 1997a, Estimating of percent vegetation cover using vegetation indices (Second COBAR, D. E., and GERBERMANN, A. H., 1991, report), Proceedings of the symposium of the Japan Society of Photogrammetry and Remote Sensing, Chiba University, Japan, 20-21 May, 1997, pp.291 Sens. Environ. 35, 105-119. -296 .

Conference papers: PUREVDORJ a, Ts., ISHIYAMA, T., TATEISHI, R., and FURUYA, T., 1996, Estimating of percent vegetation cover using vegetation indices, Proceedings of the symposium of the Japan Society of Photogrammetry and Remote Sensing, Yamagata, Japan, 8-9 October 1996, pp.101 -104 .

YOKOYAMA, R. and TSERENKHUU PUREVDORJ., 1994, NDVI in Mongolian highland derived from ground truth data and NOAA/AVHRR data, Proceedings of the symposium of the Remote Sensing Society of Japan, Hiroshima, Japan, December 1994, pp.48-52.

TANRE, D., HOLBEN, B. N. and KAUFMAN, Y. 